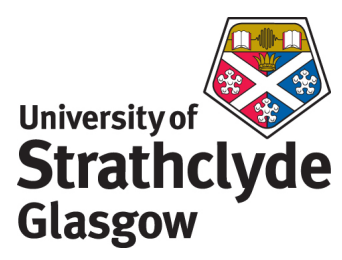

Ferguson, John (2010) Disability and the professional accountant: insights from oral histories. Accounting, Auditing and Accountability . ISSN 0951-3574 (Submitted)

http://strathprints.strath.ac.uk/28108/

This is an author produced version of a paper published in Accounting, Auditing and Accountability . ISSN 0951-3574. This version has been peer-reviewed but does not include the final publisher proof corrections, published layout or pagination.

Strathprints is designed to allow users to access the research output of the University of Strathclyde. Copyright $(C$ and Moral Rights for the papers on this site are retained by the individual authors and/or other copyright owners. You may not engage in further distribution of the material for any profitmaking activities or any commercial gain. You may freely distribute both the url (http://strathprints.strath.ac.uk) and the content of this paper for research or study, educational, or not-for-profit purposes without prior permission or charge. You may freely distribute the url (http://strathprints.strath.ac.uk) of the Strathprints website.

Any correspondence concerning this service should be sent to The Strathprints Administrator: eprints@cis.strath.ac.uk 


\title{
DISABILITY AND THE PROFESSIONAL ACCOUNTANT: INSIGHTS FROM \\ ORAL HISTORIES
}

\begin{abstract}
Purpose - This paper explores the intersection of disability and accounting employment.

Design/Methodology/Approach - The paper uses oral history accounts of 12 disabled accountants. We investigate how our narrators experience being disabled people and professional accountants, identify the barriers they encounter in professional employment, and how they (re)negotiate professional work.
\end{abstract}

Findings - Narrators' accounts are complex and diverse. Narratives record a discourse of success, offset by the consistent identification of social and environmental barriers relating to limited opportunities, resources, and support.

Originality/value - The paper: develops the limited research considering disability and the accounting profession; expands the literature considering disability and work; and augments the accumulated literature considering the accounting profession and minorities.

Keywords: Accounting Profession, Disability, Oral History, Employment, Narratives.

Paper type: Empirical paper 


\section{Introduction}

"The story we have recorded of the lives of people with disability is a story of life lived on the margins. For people with disability, their history is largely a history of silence. The lives of people with disability have not only been constructed as 'Other', but frequently as 'the Other' of 'the Other'. People with disability are marginalized even by those who are themselves marginalized."

Clapton and Fitzgerald (2005 p.1)

Historical studies of accounting employment documenting the marginalisation of minorities (Kirkham and Loft, 1993; Lehman, 1990; Lehman and Tinker, 1987; Matthews and Pirie, 2001; Tinker and Neimark, 1987) have commanded considerable attention in the accounting literature. These studies are supplemented by investigations considering such critical issues as race (Fisher, 2000; Hammond, 1997; Hammond and Streeter, 1994), gender (Ciancanelli et al., 1990; Fogarty, 1997; Haynes, 2006, 2008a, 2008b; Hooks and Cheramy, 1988; Lehman, 1992; Lowe et al., 2001; Pillsbury, et al., 1989; Spruill and Wootton, 1995; Street et al., 1993), and social class (Haynes, 2008a; Jacobs, 2003; Walker, 1988).

However, issues relating to disability and the accounting profession remain relatively unexplored. The three studies available have: first, surveyed accounting firms to establish extant disability employment practice (Authors, 2007a); second, interviewed human resource managers in accounting firms to establish gatekeeper attitudes towards employing disabled people (Authors, 2007b); and third, considered aspects of the socialization of disabled accountants (Authors, 2008). However, to date no academic research has considering how disabled accountants themselves experience and negotiate professional work. Although Authors provide quantitative (2007a) and interpretative (2007b) evidence of public accounting employers' attitudes towards disabled workers and the socialization of disabled accounting workers (Authors, 2008) we have little 
understanding of how professional accountants' negotiate disability and accounting employment. This paper then aims to fill this lacuna in the critical and interpretative accounting literature by giving voice to the silent population of disabled accountants, within a context of disability and employment, in itself an under-researched topic.

The intersection of disability and accounting employment is both socially and economically significant. United Kingdom (UK) government statistics identify that nearly one in five people of working age are disabled using legal definitions (Smith and Twomey, 2002). In addition, most developed countries have enacted legislation in the 1990s to protect the employment rights of disabled people ${ }^{1}$; e.g., the Disability Discrimination Act (DDA) (1995) in the UK, and the Americans with Disabilities Act (1990) in the United States of America (US).

This paper extends the small but growing literature considering disability and employment (e.g., Authors, 2007a, 2007b; Stone and Colella, 1996; Foster, 2007; Wilson-Kovacs et al., 2008). Our investigation provides an important extension to the steady accumulation of critical and interpretative studies of minorities in the accounting industry. Specifically the paper aims to document disabled peoples' experiences of accounting employment. The paper has three related objectives: (i) to record narrators' experiences of disability and accounting employment; (ii) to identify barriers interviewees have encountered during accounting employment; and (iii) to describe how individuals who became disabled during their working lives renegotiated employment.

\footnotetext{
${ }^{1}$ Marin et al., (2004) identify different European countries have differing expectations of how active employers will be in accommodating disabled people as employees, and also identify none have achieved the anticipated improvements.
} 
Using an oral history methodology, we explore the intersection of accounting employment and disability from the perspective of disabled accountants themselves. This approach has the advantage of being able to capture 'an increased understanding and lifeline of the past and present' (Berg, 2007 p. 277). Consequently our narrators' stories are examined from both a longitudinal historical perspective as well as the contemporary accounts elicited.

Disability activists and researchers increasingly view disability as a socially-constructed phenomenon, rather than something located within the individual. Using Oliver's (1990) seminal critique of the sociology of disability, medical (or individual) approaches consider impairment as fundamental to disability definitions, and are pervasive in the creation of social policy and legislation, yet cannot encapsulate social elements of disability. By contrast, a social approach (or social model) identifies physical, intellectual, and attitudinal barriers within society which disable people with impairments. Therefore disability represents a source of oppression imposed on people with impairments by an uncompromising society. In recognition of the political progress social model advocates have made, social definitions are now widely used in UK Government policy towards disabled people (e.g., Prime Minister's Strategy Unit, 2005), although do not feature in DDA definitions (Woodhams and Corby, 2003).

This paper is structured as follows. First, we set out a discussion of the literature considering the intersection of disability and employment, particularly in the cultural context of our investigation, the UK. This is followed by section addressing disability and the professional accounting complex. We then describe the research methodology. Specifically, we use oral history narratives from 12 disabled accountants in the UK, 
gathered over a one-year period. The experiences of our accountants are then examined and categorized into two issues: (i) being a disabled accountant; (ii) barriers to professional accounting employment; and (iii) (re)negotiating professional employment. The final section concludes.

\section{Disability and work}

The decisive decision between hope and no hope among the disabled is between working and not working. Those who work by and large feel they are part of the human race. Those who do not work feel left out, alone, and largely useless.

(Harris, 1987, 195-196, cited in Smits, 2004 p.647)

Work has long been identified as an important issue by disabled people (Hyde, 1998).

Prior to industrialization and the demands of mass-production, it was possible for people with a variety of functional and sensory impairments to be economically productive as their differences could be accommodated and skills used (Oliver, 1990). The development of factory production demanded standardised production that did not allow for physical and intellectual differences between workers. Thus 'disabled' became a term applied to those who could not meet the demands of a modern workforce (Galvin, 2006). Since the industrial revolution, disability has maintained its exclusionary relationship with work. As Galvin (2006 p.501) argues:

"the medicalisation of disability has been embedded in a framework which aims to rehabilitate or 'normalise' people with impairments so they become capable of participating in the workforce"

Consequently, conceptions of disability have been entwined with employment since the turn of the industrial revolution (Humpage, 2007), and the 'disabled' category was associated with unemployment or under-employment (Barnes, 1999). Up until the 1980s, the disabled person was said to have been largely treated as a 'helpless 
individual' reliant on 'medical and rehabilitative treatment, backed up by dependence on family and friends for assistance and/or a safety net of welfare benefits and services' (Barnes and Mercer, 2005 p.528). In addition to the obvious economic benefits that accrue to an individual from employment, work possesses "subtle psychosocial implications" (Smits, 2004 p.647) such as creating a sense of belonging, enhancing selfesteem and personal identity (Moos, 1989).

To facilitate greater inclusion of disabled people in the workforce, the DDA (1995) was enacted in the UK to prevent 'unreasonable' workplace discrimination. Broad aspects of employment are addressed by the DDA, e.g., recruitment, terms and conditions, training and development, advancement, and workplace accommodations. Critics of the DDA argue its medical, individual definitions of disability exclude certain individuals who would usually be regarded as disabled (Barnes and Mercer, 2005). Furthermore, by treating disability as an individual problem, allows organisations to adopt an individual approach to disability in organisations, creating a situation where:

the politics of disability in the workplace are therefore primarily shaped by employer willingness to accommodate disabled people rather than their right to be there

(Foster, 2007 p.82)

Research demonstrates that in the UK disabled people are half as likely to be employed as their non-disabled counterparts) (Smith and Twomey, 2002), findings supported by equivalent European-wide surveys (European Commission, 2001). Unemployment is particularly pronounced among those born with an impairment (Burchardt, 2000). Seventeen percent of individuals who develop an impairment in paid employment lose their job within a year (Burchardt, 2000). At the same time, disabled people tend to be located in lower-paid peripheral employment (Barnes and Mercer, 2005; Hyde, 1998) 
requiring fewer skills (Stevens, 2002) and are proportionately less well represented in higher-paid professional occupations (Goldstone and Meager, 2002; Wilson-Kovacs et al., 2008). Significant evidence identifies that disabled workers with similar skill levels and educational attainment as their non-disabled peers encounter fewer opportunities for promotion (Barnes et al. 1999; Berthoud, 2008; Thornton and Lunt, 1997; WilsonKovacs et al., 2008).

Despite the prevalence of disability among people of working age, in the UK for example one in five workers is considered disabled according to government statistics (Smith and Twomey, 2002), research considering disability and employment is not extensive. This perhaps reflects the widespread exclusion of disabled people from the workforce prior to the enactment of disability discrimination legislation. Investigations of disability and employment have focused on five broad issues. These include: (i) employer discrimination of disabled workers (Goldstone and Meager, 2002; Stuart et al., 2002; Wilson-Kovacs et al., 2008); (ii) employers' attitudes towards disabled people (Jones, 1997; Stevens, 2002; Stone and Colella, 2005; Stuart et al. 2002); (iii) employment law and disability (Cunningham et al., 2004; Dibben et al., 1995; Watson and Boone, 1998); (iv) labour market disadvantage encountered by disabled people (Barnes and Mercer, 2005; Prime Minister's Strategy Unit, 2005; Smits, 2004); and (v) disabled workers' experiences (e.g., Foster, 2007; French, 2004; Hyde, 1997; Levinson and Parritt, 2006; Mowry and Anderson, 1993; Roulstone et al., 2003).

Discrimination in organizations towards minorities in organizations can be categorised into two types (Jones, 1997 p.1053). First, access discrimination, where barriers exist to 'prevent stigmatised individuals from gaining employment'. Second, treatment 
discrimination encountered once employed, e.g., fewer training opportunities, limited promotion prospects, unchallenging work, and negatively biased performance appraisals.

Research suggests employer attitudes are the key antecedent of access discrimination (Cunningham et al., 2004; Jones, 1997; Stevens, 2002, Wilson-Kovacs, 2008). Notably, organisations are said to possess inaccurate negative beliefs about their productivity, aspirations for promotion, and quality of output which account for their reluctance to recruit disabled staff (Wilson-Kovacs et al., 2008). Table 1 provides an overview of empirical work considering disabled workers' experiences of employment.

Table 1 here

Once employed, Jones (1987) proposes disabled people encounter two major sources of treatment discrimination. The first relates to individual factors, directly relating to the stigma of having a disability or stereotyping (Levinson and Parritt, 2006). In a related sense, multiple stigmas may also occur, where, for example, the disabled individual is black and/or a woman. Secondly, circumstances may force disabled people to adopt selflimiting behaviours where they remain in a post or location as it allows them control over their individual circumstances (Shah, 2005).

Beyond individual factors, lie organisational factors where barriers exist as a consequence of longstanding actions and policies that limit employment of disabled people within the organisation, e.g., technology, norms and values, organizational norms and values (Stone and Colella, 1996). However, barrier removal is a complex issue frequently testing the creativity of disabled workers on a daily basis (French, 2001). Even in public sector organisations, where equal opportunities policies are typically 
more advanced than those in the private sector (Hoque and Noon, 2004), disabled workers encounter persistent problems in negotiating workplace accommodations legislated under the terms of the DDA (Foster, 2007; Wilson-Kovacs et al., 2008). In particular:

Negotiations on adjustments were highly individualised and outcomes entirely dependent upon the knowledge, attitudes and goodwill or poorly trained line managers. The adjustment process itself lead to instances of bullying by managers, leading to stress and ill health among workers.

(Foster 2007 p.67)

A common complaint made by disabled workers is the lack of advancement opportunities available (Mowry and Anderson, 1993; Wilson-Kovacs et al., 2008; Roulstone et al., 2003; Shah, 2005). At least five examples of organisational factors that limit opportunities for disabled workers can be identified. These include, first, tokenism, where the disabled person is treated as a representative of a minority rather than an individual (Jones 1987). This treatment devalues their contribution as if the individual exists to make up some quota or give credence to a diversity policy. Second, positive role models are scarce within an organisation, reflecting the limited advancement of disabled people within the organisation (Shah, 2005). Third, a situation where critical feedback is scarce (Braddock and Bachelder, 1994) exemplified by supervisors' and colleagues' reluctance to criticise the disabled worker, creating a situation where dependency on co-workers is fostered (Jones, 1987). Fourth, the scenario where the disabled person becomes the recipient of inappropriate concern and sympathy and is treated as a helpless victim (Levinson and Parritt, 2006). Fifth, a situation of denial, where non-disabled co-workers refuse to acknowledge the existence of a peer's impairment as a means of reducing 'role confusion'; a situation that extends to the position when a disabled person is located in a senior role, when stereotyping 
suggests they should occupy subservient positions (Levinson and Parritt, 2006 p.115; Wilson-Kovacs et al., 2008).

The next section considers how disabled accountants are likely to experience professional accounting employment. We draw on the limited literature considering professions and disability and theoretical frameworks of social stratification and political economy.

\section{Disability, minorities and the professional accounting context}

The extant literature suggests professions have done little to include disabled people within their ranks (French, 2001; Levinson and Parritt, 2006; Authors, 2007a, 2007b). French (2001) identifies how blind people have long practised as physiotherapists with the opening of a Royal National Institute for the Blind (RNIB) special school in 1916 for blinded servicemen, segregated from mainstream provision until 1995. However, prior to the DDA the Chartered Society of Physiotherapy 'devalued' and 'barely tolerated' the visually impaired students as a consequence 'of their lack of employment opportunities' (French, 2004 p.214). In a similar vein, Levinson and Parritt (2006 p.120) describing their personal experiences of disability and professional employment accuse their professional body, the British Psychological Society, of 'being barely aware' of 'the requirements of the DDA'.

Only limited evidence is available concerning the relationship between disability and the accounting profession with work considering to professional accounting firms' attitudes to disabled people. Three studies are available. The first surveys UK public accounting firms to determine extant practice and compliance with DDA legislation (Authors, 
2007a). A second undertakes interviews with human resource (HR) managers in public accounting firms as employment gatekeepers to elicit their views of: (i) the drivers of disability awareness; (ii) the role of partners; (iii) how firms view disability; (iv) specific impairments firms view as a problem; and (v) job applications. Findings suggest that accounting firms tend to lag other comparable private- and public-sector organizations in terms of the frequency and type of interventions available to disabled employees or partners (Authors, 2007a). HR managers in UK professional accounting firms possess an awareness of existing DDA legislation governing disability issues (Authors, 2007b); although firms' understanding of disability is limited to narrow legalistic, medicalised definitions. In particular, accounting employers were found to be slow and resistant to legislative and social change with the demands of clients and the need for mobility frequently cited as barriers to accounting employment. Authors (2007b p.35) conclude 'that the accounting profession, as a whole, is relatively inactive in dealing with issues of disability'. Applying the literatures considering the socialization of accountants and the sociology of disability, Authors (2008) identify those institutionalised practices that exclude disabled accountants, and how elements of professional socialization, e.g., image and appearance, client discourse, rigidity in accounting practice, negatively impact on the ability of the disabled to serve as accountants. In particular firms and professional bodies are described as unsupportive, inflexible, and ignorant of the needs of the disabled.

Although research exploring the relationship between disability and accounting is still embryonic, investigations considering gender, race and social class within the accounting profession, along with studies of disability and employment, provide some 
indication of how disabled people may experience accounting employment. We identify three issues.

First, a feature of the professionalization project is a reliance on closure strategies. Closure strategies encompass those processes whereby high-status groups, i.e., professions, act to maintain privileges (rights) to the inner circle (Weber, 1978). Controlling entry, by denying opportunities to outsiders and those deemed undesirable, maximises the economic rewards and social status of the profession's work and creates an artificial skills shortage. Bolton and Muzio (2007 p.52), in an analysis of the legal profession, extend the concept of closure to identify internal closure mechanisms where 'cleavages in the professions are often along the lines of gender'. Three processes are identified. First, a stratification phase in which women are excluded from senior positions. Second, a process of segmentation occurs to concentrate women in specific feminized fields. Third, a process of sedimentation takes place where women are organized within niches, creating their own powerful sub-groups.

Applying closure strategies to the context of disabled accountants, we might expect a process of stratification to exclude the disabled from senior positions within the profession or financial directorships in industry. Thus an accredited impairment becomes 'an externally identifiable characteristic' which operates as 'a pretext for their exclusion' (Weber, 1978 p.342). Segmentation might occur where particular work is deemed appropriate for accountants with certain impairments. For example, Authors (2007b) identify a reluctance for firms to deploy disabled people in client-facing roles and work involving mobility. Thus, technical, office-based work such as tax might see a concentration of accountants with accredited impairments. Finally, a process of 
sedimentation may occur when disabled people colonise a particular field of accounting work, where fewer barriers exist for people with certain impairments.

Second, despite the enactment of legislation aimed at preventing discrimination towards disabled people in employment many disability activists and academics question how effective social policy has been in advancing disabled peoples' status and inclusion. From a political economic perspective, disabled people have become part of a reserve army of workers drafted into the workforce whenever capitalism faces a labour shortage, to be removed whenever unemployment becomes apparent within the non-disabled pool of labour (Grover and Piggott, 2005). In effect, the reserve army is mobilized by government restriction of incapacity welfare benefits and enhanced surveillance and policing of benefits to create greater incentives to enter the workforce. Exclusion of disabled people in the workforce is characterised by "extraordinary short-term fluctuations' (Barnes and Mercer, 2005 p.533). For example, during World War II half a million people disabled people entered the labour force (Humphries and Gordon, 1992). As Beck (1951, p.73) cited in Burchardt (2000, p.16) observes, 'The war showed how few people were really "unemployable" on personal grounds when workers were badly needed'. However, despite government attempts to recognise its social obligation towards war-wounded soldiers, the labour market rapidly replaced disabled workers with their non-disabled counterparts (Barnes and Mercer, 2005). Consequently, we would then expect our narrators' accounts to be punctuated by periods of temporary over- and under- supply of labour. That is, in times of recession, employment will be hard to come by, and in times of full employment, employers will be more accommodating. 
Finally, a third perspective is offered by interpretative studies is offered by interpretative studies that identify the role bodies and visual appearance play in how people construct themselves and are viewed and treated by others (e.g., Bordo, 1993; Brewis and Sinclair, 2000) As Haynes (2008a) identifies:

The body is a socially constructed phenomenon, influenced by social and cultural forces, as well as a phenomenologically lived entity, through which we experience our everyday lives.

The professionalization project in accounting identifies how physical appearance, behaviour and demeanour influences performance and socialisation of the model accounting professional (Anderson-Gough et al., 1998; 2000; 2005), beyond assumed technical competence. In particular the presentation of the self plays a critical role in the disciplining of young accountants (Grey 1998).

Disabled people with visible impairments will have limited agency in how they present the own bodies and behaviour relative to non-disabled people or individuals with hidden impairments. It is likely then that the visibly disabled will encounter additional barriers to accounting employment and career development.

\section{Research methodology and context}

"Oral history has had a significant impact upon historical practice in the second half of the twentieth century. It has democratized the study of the past by recording the experience of people who have been 'hidden from history'."

$$
\text { Perks and Thomson (1998, p.ix) }
$$

Our paper uses oral history narratives of twelve disabled accountants collected in 2004 and 2005. Oral history is defined as 'the recording of personal testimony delivered in oral form' (Yow, 2005 p.3). While traditional interviews tend to be quite structured in terms of the interviewee seeking to obtain answers to a list of questions, oral history 
takes more of an unstructured approach, allowing narrators to express their voice. Traditional interviews 'usually focus on a particular experience', whereas oral histories 'deal more broadly with a person's past, and range widely over a number of topics' (Yow, 2005 p.3). The oral history approach allows us 'to understand change over time, to achieve not a static view of human experience but a dynamic view' (Yow, 2005 p.13).

Accounting scholars have recognised the value of oral history methodology. For example, Collins and Bloom (1991 p.23) propose oral history

can be used as a research tool to supplement and clarify the written record or provide a record where no written record exists; after all history is in a continuous state of revision.

Carnegie and Napier (1996, p.29) suggest 'oral history, by endeavouring to record the views of those otherwise left out of the 'archive', can provide a more rounded, and often more critical, perspective on the roles and uses of accounting'. Extending this critical view, Hammond and Sikka (1996 p.79) identify that early oral history accounts 'emphasized the importance of interviewing major personalities in the field', rather than recognizing their potential 'to give voice to the subordinated'. The power of oral history methodology is emphasized by Haynes (2008a, p.333) identifying that for narrators 'it is likely no written or other form of record already exists which may be used to document their experiences'. Recent accounting work recognises the potential of the narrative, with accounts of women and motherhood (Haynes, 2008a, b), blacks (Hammond, 2002), and the intersection of race and gender (McNicholas et al., 2004).

Oral history was chosen for our analysis of disabled workers and their experiences of accounting employment for its unique ability to provide 'eyewitnesses' (Collins and Bloom, 1991 p.23) to accounting history. Therefore, the methodology is longitudinal 
and unstructured in its nature allowing participants' first-hand accounts to directly inform the research. Furthermore the spoken word allows the interviewee to express themselves in their own 'colloquial and intimate' language, an important element of giving 'voice' to a previously marginalised group.

To recruit narrators in our oral history research, a number of avenues were pursued. First, we contacted the one professional accounting body that encourages members to self-report disability, the Institute of Chartered Accountants of Scotland (ICAS), to ask if they would be willing to provide assistance with our research. ICAS examined their database to find members who identified themselves as disabled and were of working age. A letter written by ourselves, along with a post-paid return envelope, was sent out to disabled members by ICAS to ensure members' confidentiality. Potential narrators were assured of anonymity and confidentiality. Second, we spoke to the Chartered Accountants Benevolent Association ${ }^{2}$ (CABA), a charity associated with the Institute of Chartered Accountants of England and Wales (ICAEW). CABA also inspected their database of beneficiaries to identify those members self-identified as disabled. These individuals were contacted by CABA, with our covering letter and post-paid return envelope. Again, potential narrators were assured of anonymity and confidentiality. Finally, we wrote an article for the periodical Accountancy ${ }^{3}$ (Authors, 2004) on the topic of disability and the accounting profession. At the end of the article, readers who selfidentified themselves as disabled were invited to contact the authors to participate in the oral history research. In all instances, we made it clear to narrators that our research

2 CABA was founded in 1886, with a mission to 'assist current and former Members of the ICAEW, their spouses, dependant partners and children under 18, their widowed spouses and dependant partners, orphaned children under 18, orphaned children over 18 who have special needs and other dependant persons with special need' (CABA, 2007).

3 Accountancy is the official journal of the ICAEW, and is distributed to all its members as part of the institute membership package. 
was independent of those bodies who had assisted us in identifying them, their employers, or the professional body of which they are a member. This assurance allowed narrators to speak openly of their experience.

All of the narrators were professionally qualified, six with ICAS, four with ICAEW, and two with the Association of Chartered Certified Accountants (ACCA). Additionally, one narrator also possessed Chartered Institute of Taxation membership (CTA). Nine (75\%) were men, and three $(25 \%)$ were women. Their ages ranged from 26 to 62 years at the time of obtaining their narrative accounts, a mean of 47 years of age. Or alternatively, four were aged under $44(38 \%)$ and eight aged 45 to $65(67 \%)$. According to the Financial Reporting Council (FRC, 2007), 29\% of members of the six UK chartered accountancy bodies are female. However, gender representations vary across the bodies: $40 \%$ of ACCA members are women, compared to only $22 \%$ of ICAEW members. In terms of age, some $57 \%$ of professional accountants are under 45 years of age, with $34 \%$ being between 45 and 65 years of age. Therefore, in gender terms our narrators are broadly representative of the UK accounting profession. In age terms, the narrators are slightly older than the profile of UK professional accountants. However, as the incidence of impairment is positively related to age (Grewal et al., 2003), it is expected that any sample of disabled people will necessarily be skewed by age. Three had hidden impairments, eight visible impairments, and one both a visible and hidden impairment.

A biographical summary of our narrators at the time the oral history narratives were created is provided in Table 2. Each narrator is provided with a pseudonym to allow anonymity. 
The oral history accounts lasted between forty-five minutes to three hours. As Morrissey (1998 p.110) suggests 'we should let the interviewee set his (sic) own pace; if it is slow from our viewpoint, nonetheless it is his pace'. Therefore interviews varied in duration reflecting the account the narrator wished to tell us and their availability. Before the start of each interview the narrator was provided with a statement of the objectives of the project and a list of possible discussion points. In particular our prior work considering disability and employment (Authors 2007a, b), along with our experience of the accounting profession, and accounting employment, allowed us to be properly prepared in the subject matter, a prerequisite for effective oral history work (Bornot, 1955; Collins and Bloom, 1991). With the permission of each interviewee, the narratives were recorded using a dictation machine and subsequently transcribed by ourselves. During the transcription process, careful note was made to identify points of emphasis and intonation.

Narrators were interviewed in a location of their choice which was convenient and comfortable to them. In practice this meant either their place of work, if employed; or their home, if they were self-employed or not currently in employment. The location of the interviews therefore added important contextual information concerning the individual and their employment. For example, David provided his account at the tax office where he worked, locating him in a professional context where the dual identity as a wheelchair-user and accountant was evident as he periodically struggled with his physical environment, e.g., trying to locate paper files or use the hot drinks vending machine. The meeting with Neil took place at his home, where he would demonstrate 
the technology he used to read material and work with accounting information. The context of the reading technology within his living room, his living space, amplified his account of his determination to find meaningful accounting employment within a difficult employment environment.

Disability research conducted from a social model perspective has been at times critical of research undertaken by non-disabled researchers. For example, medical research where disabled people are treated as data subjects, rather than participants, leading to their exclusion decision-making that affects them (e.g., Barton, 1996; Oliver, 1990). Consequently, as the authors of this study do not have personal experience of living with chronic illness or impairment, we believe it important to consider the ethical dimensions of this research. Specifically we assume the principles of the emancipatory research model called for in disability research (Barton, 1996). Galvin (2005) identifies three key features of emancipatory research. First, a requirement exists to prioritise the needs and well-being of narrators. Second, researchers should listen to and respect the voices of disabled people. Third, the research should aim to raise the status of disabled people. In addition, all our narrators were assured of the confidentiality of their accounts and guaranteed anonymity.

Finally, it is important to understand that we do not view our sample as statistically representative of the largely hidden population of disabled accountants. The analysis of the oral history accounts are developed to provide an insight into the experiences of disabled accountants. The views presented within the paper are intended to be indicative of the difficulties encountered and their pervasiveness. The sample is thus purposive. The aim is not to generalise but to elicit and explore experiences and attitudes, and 
deliver concepts, themes and ideas that inform future research and policy making. We now address the analysis of the oral history transcripts.

\section{Narrators' experiences of disability and accounting employment}

An obvious cleavage in the accounts relates to the point at which the narrator became disabled. Seven of our narrators had either been disabled since birth (four cases) or prior to starting their careers (three cases). The remaining five of our narrators (Alison, Dean, James, John, and Stephen) became disabled during their accounting careers. To a greater or lesser degree, this involved significant personal trauma: in part connected with their illness, but also the limitation or complete loss of their working life, status, and professional identity. For some, this was gradual and they had to grapple with the realisation that their impairment was beginning to affect their work.

"I have a hearing loss and that's meant that, in the course of my work, I asked not to have to deal more than was absolutely necessary, because I find that particularly on the telephone with people with fractured English was becoming very difficult."

(Dean)

Or could be temporal:

"I was diagnosed with MS in 1991. I started getting the first symptoms in the 80s. Every couple of years I had relapsing, remitting MS. So in the early days it came and went quickly. By 1995, it was too much, running a business." (John)

For others, the situation was more traumatic, and sudden:

"I had a stroke... which left me with paralysis of my left arm and leg, poor spatial awareness and divided attention. I was a partner in a firm of chartered accountants. It just occurred one day out of the blue..." (Stephen)

Gwen had two impairments: manic depression which started when she was a teenager, and chronic fatigue syndrome which occurred just two years ago, when she was 38 years of age. Gwen had only recently returned to the UK from a country in southern Africa 
where she had been working as an accountant. In her view, this country had a more progressive view to disability than the UK:

"It's [name of country] a very inclusive society type-of working atmosphere... They were very inclusive there, I used to be on the council body for [name of country], the Chartered Accountant Council Body, and we were very strict on the race thing, but also gender and they were starting to think about precedents for disabled, so yeah, they were thoughtful on that one."

For those that had been disabled from birth (David, Joan, Neil, and Peter), their impairment was an essential characteristic of the self. For example:

"I think that my disability, because I've had it from birth, has moulded my character, and because I've been disabled I'm a completely different person than if I hadn't been disabled." (Peter)

The analysis of narrative accounts revealed whether the impairment was hidden or visible was an important factor in determining our interviewees' self-concept and how they were treated by others. Seven of our interviewees had impairments which were clearly visible. Gwen exemplified this issue, with a visible impairment (chronic fatigue syndrome) and a hidden one (chronic depression). Referring to the latter, Gwen said:

"I never ever saw my chronic depression as a disability." (Gwen)

However, she explained:

"There are times when I've been in a wheelchair and I've been treated like an idiot, as if I should be dribbling." (Gwen)

This analysis directly relates to the social model of disability. Her depression is hidden, and she encounters few social barriers as a consequence. Thus, the impairment remains just that, and in the absence of social oppression is not constructed as a disability. However, as a wheelchair-user, she encounters intellectual barriers, framing how an individual with a visible impairment is stigmatized (Jones, 1987; Levinson and Parritt, 2006). Gwen's comments suggest her identity as a wheelchair-user is clearly at odds with the perception of the accounting professional. Her view that her hidden impairment 
wasn't 'a disability' emphasises how impairment doesn't coincide with popular beliefs of what constitutes the embodiment of the professional accounting worker (Haynes, 2008a, 2008b).

For Alison having a hidden impairment, also framed others attitudes towards her:

"My employer's aware that I've got problems. Whether they'd call me disabled or not, I don't know, because it's something that's developed as I've been here. They didn't take me on as being a disabled employee. They're conscious that they have to do things for me and they're conscious that I have to be careful what I'm doing and all the rest of it. I'm not sure whether they'd actually class me as a disabled employee or not."

The nature of Alison's impairment, Ehlers-Danlos Syndrome, meant that her 'problems can sort of change from one week to the next'. This affected the way she was treated by colleagues, who at times found it difficult to understand how impairment could be temporal. She alluded to a sense of frustration and confusion about others' attitudes to this. For her employer the absence of a physical condition created a situation where it was questionable whether she was actually disabled, emphasising the role presentation of the self plays in accounting employment.

All the people interviewed in this investigation had at least at some point in their lives, a strong sense of professional status. For each of the five interviewees presently working as an employee (Alison, Andrew, David, Gwen, and Peter), they were the only disabled person in their workplace. For example, David commenting on his experience of being recruited by a Big Four firm said:

"When I did my interviews I asked whether there were other disabled people in the firm and certainly the interviewer didn't know. I suppose the closest I've come to seeing someone else who was disabled was, we used to have someone in here with MS. You'd have thought with the size of [name of Big Four firm] you would do" (David) 
David's experience raises four issues. First, the interviewer is unaware of the incidence of disability within the Big Four firm. However, the interviewer is likely to be wellinformed about the firm and its staff and partners ${ }^{4}$. Second, despite David having worked for the firm for five years, he had met no other employees with impairments within the firm. As a trainee, his socialisation process would have exposed him to a wide range of other trainees and staff up to partner level. Third, his comments on meritocracy refer to a combination of academic and personal qualities required for success as a chartered accountant, while possessing an impairment that is perceived to be easily accommodated. At interview David was steered away from audit towards tax by the staff partner as 'it would be easier to do... because it was more office based'.

Narrators' experiences tended to relate to prevailing employment practices and labour market conditions at the relevant point of their oral history. For example, Euan explained his securing a traineeship in the late 1960s was due to patronage:

"I got my firm that I worked for through a friend of my father who was a solicitor. Again, it wasn't what you knew but who you knew. It was that way that I got in. I didn't really have to shop around very much. I got in to a training office, or an office as it was then, which was accessible, a relatively modern building. It had a lift and the rest of it." (Euan)

Andrew, seeking a traineeship (apprenticeship), just a little later than Euan, had a more vexing experience:

"Initially when I started up as an apprentice, when I joined the apprenticeship, that it happened and initially I didn't tell the employers that I had epilepsy, but one of them discovered and wasn't too pleased with the agency that had sent me to them. He went back to them and asked for a refund." (Andrew)

Gwen had similar difficulties explaining that she had encountered problems in:

\footnotetext{
${ }^{4}$ This is perhaps not a surprising comment. Reading recent Annual Reviews produced by the Big Four firms in the UK only one invites employees to self-identify whether they consider themselves as disabled (KPMG), and that only 19 employees (of 7,500) are prepared to identify themselves s disabled (KPMG, 2006).
} 
"Trying to get work and declaring that you have a disability. I've been trying to approach CA firms to try and get some flexible work that I'd be able to do. I don't even get the courtesy of a reply or a response, I've replied to an advert in the paper saying that I have a disability but I could work, I show how I could fit in, and I just get a standard letter back, which I know I've got the qualifications, so what's their problem?" (Gwen)

Andrew and Gwen's experiences highlight the paradox faced by disabled job applicants: if they disclose an impairment, they are excluded. However, if they hide their impairment, they face disciplinary action. In Andrew's case, a colleague who knew him disclosed his impairment to the partner. For Andrew, it highlights the reluctance to make any form of accommodation for an individual with an impairment, essentially objectifying them (Shakespeare, 1997) as a reject requiring a 'refund' from the supplying agency.

When a trainee accountant with an impairment found work it could be on inferior terms and conditions to other employees. Neil explained his experience of gaining trainee work experience prior to the DDA was that:

"[Name of firm] I was with, it was a small firm and they employ people, usually placement schemes, but I was on a sub-contract. And they brought the sub-contract to an end with very little notice... They gave me an extension till the end of January and it was curtailed to the end of the month... They curtailed it otherwise they might be liable for compensation. It was curtailed without notice. Whereas, opposed to all the other people on employed contracts, who didn't have a disability, they obviously had to go through a procedure to terminate the contracts. And because I was on a subcontract it was... not necessary to do that." (Neil)

Neil's treatment therefore identifies how being a disabled person could mean accepting inferior terms of conditions of employment, reflecting the concerns of paying compensation. Poorer terms of service were identified by two other accountants, Andrew and Euan, both of whom had been paid below the 'going rate'. For example, describing employment on qualification, Euan recalled: 
"The first job I got when I moved down South was fine but I had people who were at the same level as myself in the office and their salary increases seemed to better mine... That was probably one thing that made me look towards the idea of selfemployment... From that point of view it sort of energised me, the clients always seemed to get on with me, and touch wood, the work seemed to be done right." (Euan)

Euan's final remark is interesting as it alludes to how overcoming discrimination is empowering and, perversely, a catalyst for advancement. Euan's ability to cope with adversity was an expression of strength gained by overcoming discriminatory barriers all his working life.

Participants frequently described how they felt they were marginalised from their organisations altogether, becoming either self-employed or finding work in smaller regional firms which were more accommodating. For example, James explained:

The easy option is to work from home. I think you find if you look at gender as well, a lot of women if they can't get a job as chartered accountants go and work for themselves at home. That's why you see less discrimination. It's not because there isn't discrimination, because the other route is to go self-employed. And as you know, disability has one of the highest rates of self-employment anyway. I think most disabled accountants would go down the route of self-employment, rather than go through the hassle (James)

Joan, who is involved in a voluntary capacity with an organisation for disabled professionals, explained that many disabled people are attracted to self-employment because sometimes they find nine to five hours difficult. Joan added: "they have got clients, but they can ask them to come at times which is convenient to them, rather than the other way round".

Gwen noted a difference between Big Four accountancy firms and smaller regional firms, in terms of their attitudes towards disability. She explained:

"Smaller firms tend to be more personal in terms that they're more willing to accommodate the individual needs of all their employees, not just disabled employees. Whereas with larger firms you have to fit into the plan. If you're not 
able to work for any reason on that particular day well then it's a problem, and you're the problem not the firm." (Gwen)

Collectively, these remarks go some way to explaining the closure strategies adopted by the profession. On the basis of narrators' experiences, disabled people are more likely to be segmented into self-employment and smaller regional firms; options less attractive to non-disabled people.

The relative isolation of disabled accountants often meant that the individual became 'the expert' on disability issues within their firm, or company. However, this reflected the presence of the Disability Discrimination Act 1995:

"They know that when I tell them something they are going to have to do it because they know what I'm like and that I've got the law behind me. Whereas ten years ago, it was a suggestion: they might consider doing it." (Peter)

"I'm a designated health and safety person as well. Partly it's part of my job to go to them and advise them, and partly because it's me that's got most of the problem." (Alison)

The change in discourse between Peter and Alison reflects their differential age, experience of disability, and conceivably, gender. Peter has adopted a disabled identity all his life; for Alison, disability has been more recent. As a District Councillor, Peter is politically active, chairs the Council Access group, and has experienced employment as a disabled person prior to the DDA. Alison by contrast, is less confident in reconciling her disability, 'the problem', with her professional identity as an accountant.

Overall, the accounts identify a number of recurrent themes. Disabled accounting workers are generally isolated and encounter problems in finding employment, where the issue of whether to reveal or conceal an impairment, and a disabled identity, creates a real dilemma. This insight sheds some light on prior research identifying accounting 
employers believe they have few disabled applicants because of the onerous nature of accounting, the "very long hours, travelling out to clients... maybe that puts people off" (Authors, 2007b p.32). Our findings suggest that job applicants to the accounting profession believe that disclosing a disability will lead to discrimination. Depressingly, this suspicion is confirmed by narrators' accounts that job opportunities for disabled accountants are more limited than for their non-disabled peers. Often when the individual is hired it could be on inferior terms and conditions, where they were perceived to be in a weaker negotiating position than other candidates.

\section{Barriers to professional employment and renegotiating professional work}

Each of our 12 narrative accounts revealed each narrator had encountered some barriers to working as a professional accountant. There was a continuum of experiences, from a situation where the individual had been sidelined into undertaking work other firms of small accountants didn't want to, for example, preparing accounts for small taxi firms (Euan), to a position where the person had no option but to leave employment (Dean, James, Gwen, Joan, John, Stephen).

In other instances, the individual could be the unwitting beneficiary of office technology designed to make them more productive:

"More recently they were looking at trying to speed up my work, to help me to work faster so they asked me how I felt about the speech dictation software where I could wear headphones and talk into the computer. And I told them I'd never used it before and they were interested in my trying it out. I was a bit concerned because obviously this software costs a lot of money. I said to them, 'Look if it doesn't work, it's a lot of money wasted', but they were keen to do it. So they got the software in, but I didn't really get on with it at all. So in a way I felt a little bit bad that a lot of money had been wasted, but it was their choice in the end." (David)

Despite David's willingness to be flexible and try the new equipment, there is also a suggestion that he is concerned that his (in)ability to cope with new equipment was 
regarded negatively by the firm. Consequently David is made to feel guilty about his inability to adapt to the new productivity technology.

For others, workplace accommodations made by their employers were less charitable. Neil explained that as a trainee accountant employed on a sub-contract, the equipment bought using government grants for him by the employment agency he worked for was purposely retained by the small firm using his services. The retention was in spite of the fact that the employer had no obvious immediate need for the equipment:

"And he was insistent that he wanted a large screen monitor and all the other adjustments and things they had made to the computer, the laptop and everything else. He even wanted to keep my pen thing which I use to transfer data. He said it might have confidential data on it, I'll have to try and keep it." (Neil)

At the other end of the continuum, in the more minor instances, the individual was the subject of disparaging comments:

"we actually relocated office from one part of this building to another part, and again I declined in helping moving furniture and papers, and again - the rest of my work colleagues were very supportive, but again my FD was sarcastic with the fact that I wasn't helping relocate. And again, I felt justified because I'd done all the lifting and carrying things of which I was capable." (Peter)

These remarks are designed to weaken the individual in at least two ways: Peter is made not to feel as part of the team because they are unable to lift furniture; whilst those professional skills he possesses are ignored, because he lacks the capacity to undertake manual work.

If our interviewees became disabled during the course of their employment, invariably this meant disruption to their professional lives. Similar to other studies of disability and professional employment, negotiations were often highly individualised leading to varied outcomes for the disabled worker (Foster, 2007; Wilson Kovacs et al. 2008; 
Roulstone et al., 2003; Shah, 2005). When the onset of the impairment was gradual, or temporal, this provided greater scope for adjustment. For example, as Chris' hearing became progressively worse, he could move from the Head of Finance in an international bank, to the Head of Compliance, as this required less work involving telephones. John's onset of MS allowed them to keep working for four years after diagnosis. By contrast, Stephen explained that he had little option but to retire. When he was asked about the consequences of this, Stephen explained that he 'had no alternative but to resign' because:

"there are some provisions in the Partnership agreement whereby that if the Partner is away for a his duties if you like, the other Partners could actually ask him to resign or leave the partnership" (Stephen)

At the point of experienced illness or impairment, our narrators identified a common experience of encountering coercive pressure to remove them from employment. But for the individual, exiting career and employment was not an easy option. For example, Joan identified family responsibilities:

"I had rather been pushed out by then, more than anything else Looking back I couldn't leave because of my daughter, and that put a lot of pressure on me, and [name of multinational company] were pushing for me to leave anyway." (Joan)

When asked to explain why she felt 'pushed out' Joan explained:

"I wasn't being promoted. They were giving me work that was below my ability. I became more and more frustrated... I went to see the medical officer at the time and said 'look I don't want the redundancy package, if you want to get rid of me, you have got to give me something back'." (Joan)

Eventually, Joan managed to negotiate a package whereby she received an income from her employer and incapacity benefit.

When our interviewees stopped working as accountants because of their disability, their identity as professional accountants diminished. This often reflected the serious change 
in economic circumstances. James, reflecting on his career as a junior partner with a Big

Four firm described that he sat 'at the desk next to' other accountants who went onto to

be senior partners in the firm. Referring to his peers, he explained that:

"Many of them have taken early retirement, rather than the other way round. I think the difference is that I was, what would I have been? 35, that's the age I stopped being an accountant. Most of them would have been in their late forties, early fifties. I think that's the difference. I mean I was at the stage where most chartered accountants start to reap some of the rewards... I mean they have retired on good final salaries. And what I got was nothing by the time we had finished. And that the other thing, you just stop, it stops." (James)

James had received financial support from the Chartered Accountants Benevolent Association, who provided assistance in the mid-1980s 'when I desperately needed a car and a wheelchair'. By contrast, David, a much younger accountant, volunteered a different view of CABA.

"To me, getting something through the post asking me to contribute to a fund to look after Chartered Accountants who probably have had a fair earning power over their careers. You know when you think of things like the Tsunami, Africa, to me they seem to be much more worthwhile charities than the Benevolent fund." (David)

David's analysis of the apparent wealth of chartered accountants contrasts strongly with James, whose plans for the future literally terminated with the onset of his condition. James explained:

"I think a lot of chartered accountants and their wives, or their wives of ex-chartered accountants who have died, who have been involved in a very raw deal. Probably because chartered accountants are seen as rich people, like this bungalow here. The only reason I got this bungalow is because I bought it when I was... you know, as long as 25 years ago. That's the only reason we can afford it, because we bought, we paid for it in those days." (James)

Cohort effects are evident throughout the narratives. In particular the ability of narrators to retain or find employment is strongly related to the economic cycle. Where non disabled workers are feely available in a recession, disabled accountants had 
considerably less opportunity to find work (Andrew, Euan, John, Neil) providing some justification for the political economic 'reserve army' hypothesis.

In summary, the narrators identified a number of barriers to professional employment. At the lower end of the spectrum these included unpleasant remarks and negative attitudes, to workplace accommodations designed to make the individual more productive, through to pressure to leave employment. Invariably the accounts identified a common theme of marginalisation where disabled workers were located in roles that were relatively unattractive to others, e.g., self-employment working from home or working for smaller firms.

\section{Discussion}

The purpose of this paper was to consider the interaction of disability and professional accounting employment. Given the dearth of extant work in this field, consideration was given to the limited prior research documenting employment and disability. We do not profess that the narratives of the accountants of our study are necessarily representative of the broader, hidden and silent stories of similar people within the profession. The disabled accountants within this study are not a homogenized group. Rather, the oral histories record different private, domestic and public, professional life experiences which differ according to age, social and economic circumstances, and professional specialisation.

The accounts serve a valuable function in providing social justice for disabled professionals, in recognising their demands for equality, and their identification of 
disabled accountants as valid and significant members of the profession. Furthermore, we believe our narrators' experiences provide inspiration for new ideas about disability and professional employment, and minority groups and the accounting profession. As identified in the introduction to this paper, disabled people of working age are a significant minority in terms of their frequency and benefit from increased levels of legislation designed to protect their employment rights. Legislative effort towards the disabled has lagged both race and sex discrimination (Authors, 2007b). Therefore work examining the viewpoint of disabled accounting workers provides some clues how women and blacks might experience employment if legislation had been enacted much later.

A peculiarity of a disabled identity is its temporal nature. An individual may become disabled in an instance of time, through an accident or illness. By contrast, individuals are unlikely to change their gender or religion overnight; such a change would require some form of structured process. The inability of employers of accountants to cope with this change in identity was apparent from narrators' accounts. Inevitably, becoming disabled is a major life event for any individual; the low level of support from employers does little to assist the disabled worker. The process of renegotiating professional work parallels Haynes' (2008a, b) accounts of pregnant women accountants' struggle to achieve acceptance for what is for most a normal, and celebrated, life event of becoming a mother.

Analysis of the oral histories reveals two competing stories. First, a discourse of success illustrated by professional status and overcoming individual and organisational barriers to employment. Most narrators' depicted professional accounting employment as a 
positive entity and a potential source of emancipation. A second story points to discrimination, a lack of organisational knowledge of issues relating to disability and employment, and an inability to address barriers to employment. For disabled accountants in employment today this suggests a paradox. On the one hand, disabled people receive some protection under law and are entitled to some level of accommodation from their employer. However, this support is frequently offset by a lack of consideration of their needs, and limited professional development and promotion opportunities (Barnes and Mercer, 2005; Foster, 2007; Wilson-Kovacs et al., 2008). Although employment legislation has had a wide ranging effect on disabled workers status, demands for equality of opportunity and social justice are not yet fully recognised.

As might be expected the most marked difference in our narrators' experience of employment related to whether they had become disabled before starting their careers, or if their impairment or long-term illness occurred during their working life. When people had entered accounting with an identity as a disabled person, their careers were carefully negotiated around their impairment. This would typically mean the identification of work where travel would be minimised, and where workplace accommodations could be made. However, none had managed to break into the most senior positions within the profession or industry, suggesting a process of disability stratification (cf., Bolton and Muzio, 2007). David's belief that he was the only disabled professional accountant within his Big Four firm clearly points to the lack of positive role models.

Those who entered accounting as disabled people undertook a range of accounting work. Work-domains included audit and accounting (Alison, Euan), company accounting 
(Joan, Peter), public-sector accounting (Gwen), and taxation (Andrew, David, Neil). The variety of work activities revealed within the narratives suggests at this stage disabled accountants have not undergone a process of segmentation, whereby disabled people are condensed within certain niches. However, two popular work domains for disabled accountants were apparent. First, self-employment was seen to allow for greater individuality (Euan and John); and second, taxation was popular as it minimised the necessity for travel (Andrew, David, and Neil). With at least one Big Four firm and one UK professional body now encouraging their people to self-identify themselves as disabled, the enactment of disability rights legislation over a decade ago, and the development of serious academic accounting work considering disability, it is plausible that in future the population of disabled accountants will become more visible, making segmentation work more viable.

For those that developed an illness or impairment during the course of their career, the process of coming to terms with their disability and employment represented an epiphany. In particular the burden of an impairment created a loss of independence and difficulties in negotiating accounting employment. For some, the process was gradual reflecting a degree of denial, and a slow identification of social, physical and intellectual barriers which define disability in a social sense (Dean, Gwen, and John). For others, circumstances meant their occupational status changed overnight (James and Stephen).

Another distinguishing feature of narrators' experiences was a cohort effect. This is explained by three factors. First, the enactment of legislation, the DDA (1995), that provides some protection for disabled workers. Disabled people seeking or negotiating accounting work prior to 1995 received little in the way of employment protection. 
Second, the prevailing economic circumstances that dictate the employability of disabled people. For example, high unemployment in the 1980s and early 1990s has given way to current skill and labour shortages, necessitating utilization of the reserve army (Grover and Piggott, 2005). The third factor was the juncture in their career when the individual became disabled. For example, when Dean first encountered hearing loss, he could transfer to still relatively lucrative employment as Head of Compliance and then retirement with the support of a well-funded occupational pension, accrued in earlier years. By contrast, James' unemployment at 35 years of age as a junior partner meant the complete loss of economic opportunity and reliance on charity.

The paper also explored the relationship between being a disabled person and professional accountant. This demonstrates the interaction of private and public lives, where the individual has to privately negotiate and balance impairment or long-term illness with the public sphere of professional work. Although most accountants had managed to negotiate some form of workplace accommodation (Alison, David, Dean, Gwen, Joan, John, Peter) they still regularly encountered individual and organisational barriers. Examples included: a lack of understanding and consultation about the person's needs; stereotypical views of disability; a dearth of role models; difficulties concerning the fluidity of public and private time; mobility problems limiting promotion opportunities; the imposition of technology as a productivity tool; and in James' and Stephen's case, outright dismissal. Alongside these sit instances of participants enduring unpleasant, undermining remarks and other humiliating behaviour now treated as 'disability harassment' under the 2004 amendments to the DDA 5 .

\footnotetext{
${ }^{5}$ Section $3 \mathrm{~B}(1)$ of the DDA.
} 
Narrators with visible impairments, who formed the majority of our narrators, tended to encounter more significant barriers than interviewees with hidden impairments. Evidence was found that the desired conception and demeanour of the model accountant conflicted with possession of a sensory or physical impairment. In particular this was evident with one participant with both a visible and hidden impairment (Gwen). Although the hidden impairment was likely to have as great an impact on her ability to undertake accounting work (chronic depression), the use of a wheelchair seemed to pose greater problems, to the degree that the depression was not viewed by the individual as a

It is evident from the narratives that the dual identities as disabled people and professional accountants are closely interlinked, rather than opposed. This reflects in part the centrality of work to the self by the norms and structures of society (Moos, 1989; Smits, 2004). Historical research identifies to be labelled 'disabled' means to be excluded from the workforce. Most of the narrators in this study were either: unemployed; or under-paid, and confined to the margins of the profession.

Those accountants who faced the onset of impairment during their working careers inevitably encountered an economic and social transformation exemplified by reduced independence and the loss of employment status and opportunities. This alteration to their personal circumstances were heavily influenced by the negative attitudes of others and interfered with employment as an accountant. Work considering professional accountants and disabled people reveals inequalities within the accounting profession, and allows for greater understanding of disabled people within an occupational context.

\section{Conclusions}


Our investigation contributes to the accumulated evidence concerning other minority groups within accounting employment illustrating individual struggles to overcome inequality. As the quotation beginning this paper suggests, disabled people and, by implication, disability studies have existed at the margins of existence. We hope then to have highlighted the need for the greater inclusion of disabled people in the accounting industry, an under-explored and critical subject which will be the subject of further academic investigation.

This paper contributes to an understanding of disabled peoples' experiences of accounting employment, an area unexplored by other accounting researchers. Our investigation complements the relatively limited literature available documenting disabled professional workers (French, 2001; Shah, 2005; Levinson and Paritt, 2006; Foster, 2007; Wilson-Kovacs et al., 2008). As others have identified, disabled workers face unequal treatment between themselves and non-disabled peers (e.g., Hyde, 1998; Mowry and Anderson, 1993); in this respect our oral histories are no different.

Despite the passing of potentially powerful disability anti-discrimination legislation in the mid-1990s inequalities still exist, albeit in more subtle forms. For example, an employer may wish to interview a disabled applicant, yet steer them away from some avenues of employment such as auditing on the pretext that such work involves significant travel or 'mobility'. Yet it is equally plausible, as we have identified elsewhere (Authors, 2007b), that they are being steered away from face-to-face contact with clients. 
Despite the potential accounting employment offers to many individuals with various impairments, it seems that employers of accountants are reticent to provide equality of opportunity for disabled people. This leaves disabled accounting workers either marginalised to undertake work others do not wish to do, seek self-employment, work in other fields, or accept unemployment. Our interviews therefore provide direct evidence of the exclusion of disabled accountants that prior work considering accounting employer perspectives (Authors, 2007a, 2007b) suggests.

In particular, the investigation highlights differences in employment experience between accountants with hidden and visible impairments. Possession of a hidden impairments obviously allows the individual the option of concealment; an alternative that carries a burden that could result in their dismissal if applying for a post or if in work, anxiety and stress that their employer may seek to downgrade them or ultimately seek to terminate their employment. Our historical accounts provide good cause for these concerns, with those narrators becoming disabled documenting employers' strategies to remove them employment, either instantly or using a variety of formal processes.

It is plausible today that such formal strategies would be less likely given the passing of successive anti-discrimination legislation. Yet recent research (Foster, 2007) documents that despite the DDA (1995) negotiations for workplace adjustments for disabled workers remain highly individualised and dependent on the benevolence, or otherwise, of frequently unknowledgeable line managers. Our accountants pointed to a variety of more subtle techniques used to marginalise disabled workers that included unhelpful remarks, an inability to make accommodations, and the use of inferior terms and conditions of employment relating to pay and prospects. Prior studies of accounting and 
other professional employers identify the importance of discourse and informal processes in exclusion of minority groups; future interpretative work could consider more closely how such mechanisms restrict disabled peoples' inclusion within the accounting industry.

The low visibility of disability in the accounting workforce suggests the Weberian closure strategies of stratification, segmentation, and sedimentation remain at an early stage. Evidently the profession is stratified in such a way that excludes the disabled from senior positions and some evidence suggests that disabled accountants are occupying certain technical, office-based roles such as tax and self-employment. We would expect in that in future a process of sedimentation will occur whereby disabled accountants start to colonise these job roles in the industry. How fast this process occurs and how disabled people fare relative to non-disabled peers remains to seen (cf. French's 2001 analysis of the longstanding struggle the blind encountered for acceptance into the physiotherapy profession despite lengthy professional training at a specialist college).

With the enactment of legislation protecting disabled people in most developed countries, the potential disabled people offer to the accounting employment in an era of relatively low unemployment and skill shortages, their legitimate demands for social justice and equality, the growing acknowledgement of the frequency of disabled people within higher education and the UK economy and the slow recognition of disability by a few accounting institutions, it remains to be seen what progress disabled people make within the accounting profession.

\section{REFERENCES}


Authors (2004), "Room for Improvement”, Accountancy, (December), pp. 66-67.

Authors (2007a), "Disability and accounting firms: evidence from the UK", Critical Perspectives on Accounting, Vol. 18 No. 2, pp. 139-157.

Authors (2007b), "Issues concerning the employment and employability of disabled people in UK accounting firms: an analysis of the views of human resource managers as gatekeepers", British Accounting Review, Vol. 39 No. 1, pp. 15-38.

Authors (2008), "Disability and the socialization of the professional accountant", Paper presented at the Critical Perspectives on Accounting Conference 2008, New York.

Barnes, C. (1999), "Extended review: disability and paid employment", Work, Employment and Society, Vol. 13 No. 1, pp. 147-149.

Barnes, C., and Mercer, G. (2005), "Disability, work and welfare: challenging the social exclusion of disabled people", Work, Employment and Society, Vol. 19 No. 3, pp. 527-545.

Barnes, C., Mercer, G., and Shakespeare, T. (1999), Exploring Disability: A Sociological Introduction. Polity Press, Cambridge.

Barton, L. (1996), Disability and Society: Emerging Issues and Insights, Longman, Essex.

Berg, B.G. (2007), Qualitative research methods for the social sciences. Pearson, Boston, MA.

Berthoud, R. (2008), "Disability employment penalties in Britain", Work, Employment and Society, Vol. 22, No. 1, pp. 129-148.

Bolton, S. and Muzio, D. (2007), "Can't live with 'em, can't live without 'em", Sociology, Vol. 41 No. 1, pp. 47-64.

Bordo, S. (1993), Unbearable weight: feminism, western culture, and the body. Berkeley: University of California Press.

Bornot, V.D. (1955), "Oral history can be worthwhile", American Archivist, Vol. 18, No. 3.

Braddock, D., and Bachelder, L. (1994), The glass ceiling and persons with disabilities, Key Workplace Documents Federal Publications. Ithaca, NY: Cornell University Press.

Brewis, J. and Sinclair, J. (2000), Exploring embodiment Women, biology, and work. In J. Hassard, R. Holliday, and H. Willmott (Eds.) Body and Organization. London: Sage.

Burchardt, T. (2000), Enduring Economic Exclusion: Disabled People, Income and Work. York: Joseph Rowntree Foundation. 
Carnegie, G.D., and Napier, C.J. (1996), "Critical and interpretative histories; Insights into accounting's present and future through its past", Accounting, Auditing and Accountability Journal, Vol. 9 No. 3, pp. 7-39.

Chartered Accountants' Benevolent Association (CABA) (2007), About us. www.caba.org.uk

Ciancanelli, P., Gallhofer, S., Humphrey, C., and Kirkham, L. (1990), "Gender and Accountancy: Some Evidence from the UK", Critical Perspectives on Accounting, Vol. 1, No. 2, pp. 117-144

Clapton, J. and Fitzgerald, J. (2005), The history of disability: a history of 'otherness' Renaissance Universal. Available at www.ru.org/artother.html.

Collins, M. And Bloom, R. (1991) The role of oral history in accounting, Accounting Auditing, and Accountability Journal, 4 (4), 23-31.

Cunningham, I., P. James, and P. Dibben. 2004. "Bridging the gap between rhetoric and reality: Line managers and the protection of job security for ill workers in the modern workplace", British Journal of Management Vol. 15, pp. 274-90.

Dibben, P., James, P. and Cunningham, I. 2001. "Senior Management Commitment to Disability: The Influence of Legal Compulsion and Best Practice", Personnel Review, Vol. 30 No. 4, pp. 454-467

European Commission (EC) 2001. Diamontopolou Earmarks 2003 as European Year of Disabled People, E.C., Brussels.

Fisher, L. (2000), Is the Profession Colour Blind? Accountancy, December, pp.42-43

Fogarty, T.J. (1997), “Towards progress in gender research in accounting: challenges for studies in three domains", Asia-Pacific Journal of Accounting, Vol. 4 No. 1, pp. $37-58$.

Foster, D. (2007), "Legal obligation or personal lottery? Employee experiences of disability and the negotiation of personal adjustments in the public sector workplace", Work, Employment and Society, Vol. 21 No. 1, pp. 67-84.

FRC (2007), Key Facts and Trends in the Accountancy Profession. London: The Financial Reporting Council Limited.

French, S. (2001), Disabled People and Employment: A Study of the Working Lives of Visually Impaired Physiotherapists. Aldershot: Ashgate.

French, S. (2004), "Disabled health and caring professionals: the experiences of visually impaired physiotherapists". In: Disabling Barriers - Enabling Environments (Eds. J. Swain, S. French, C. Barnes, C. Thomas) pp. 212-218, London: Sage. 
Galvin, R.D (2005), Researching the disabled identity: contextualising the identity transformations which accompany the onset of impairment. Sociology of Health \& Illness, Vol. 27, No. 3, pp. 393-413.

Galvin, R. (2006), "A genealogy of the disabled identity in relation to work and sexuality", Disability \& Society, Vol. 21, No. 5, pp. 499-512

Goldstone, C., and N. Meager. (2002), Barriers to employment for disabled people, Department for Work and Pensions in-house report 95. London: Department for Work and Pensions.

Grewal, I, Joy, S., Swales, K., and Woodfield, K. (2003), Disabled for Life? Attitudes towards, and experiences of, disability in Britain, Research Report No 173, London: Department for Work and Pensions.

Grover, C., and Piggott, L. (2005), "Disabled people, the reserve army of labour and welfare reform", Disability and Society, Vol. 20, pp. 705-717.

Hammond, T.D. (1997), "From Complete Exclusion to Minimal Inclusion: African Americans and the Public Accounting Industry 1965-1988", Accounting, Organisations and Society, Vol. 22 No. 1, pp. 29-53

Hammond, T.D. (2002), A white-collar profession; African American certified public accountants since 1921. North Carolina: University Press.

Hammond, T.D., and Sikka, P. (1996), "Radicalising accounting history: The potential of oral history", Accounting, Auditing and Accountability Journal, Vol. 9, No. 3, pp. 79-97.

Hammond, T.D., and Streeter, D.W. (1994), "Overcoming Barriers: Early AfricanAmerican Certified Public Accountants", Accounting Organizations and Society, Vol. 19, No. 3, pp. 271-288.

Harris, L. (1987) Inside America (New York, Vintage).

Haynes, K. (2008a), "(Re)figuring accounting and maternal bodies: The gendered embodiment of accounting professionals",. Accounting, Organizations and Society, Accounting, Organizations and Society, Vol. 33, pp. 328-348

Haynes, K. (2008b), "Transforming identities: Accounting professionals and the transition to motherhood", Critical Perspectives on Accounting, 19, pp. 620-642.

Haynes, K. (2006), "Linking narrative and identity construction: using autobiography in accounting research",. Critical Perspectives on Accounting, Vol. 17 No. 4, pp. 399-418.

Holland, D., Lachicotte, W., Skinner, D., and Cain, C. (1998), Identity and agency in cultural worlds. Cambridge, MA: Harvard University Press. 
Hooks, K.L., and Cheramy, S.J. (1988), "Women accountants - Current status and future prospects", Journal of Accountancy, May, pp. 18-28.

Hoque, K., and M. Noon. (2004), "Equal opportunity policy and practice in Britain: Evaluating the 'empty shell' hypothesis",. Work, Employment and Society Vol. 18, No. 3, pp. 481-506.

Humpage, L. (2007), "Models of Disability, Work and Welfare in Australia", Social Policy and Administration, Vol. 41 No. 3, pp. 211-230.

Humphries, S. and Gordon, P. (1992), Out of Sight: The Experience of Disability 19001950. Plymouth: Northcote House Publishers.

Hyde, M. (1998), "Sheltered and supported employment in the 1990s; the experiences of disabled workers in the UK", Disability \& Society, Vol. 13, No.2, pp. 199-215.

Jacobs, K. (2003), "Class reproduction in professional recruitment: examining the accounting profession”, Critical Perspectives on Accounting, 14 (5), 507-616.

Jones, G.E. (1997), "Advancement opportunity issues for persons with disabilities", Human Resource Management Review 7, 1, 55-76.

Kirkham, L., and Loft, A. (1993), "Gender and the construction of the professional accountant", Accounting Organisations and Society, 18 (6), 507-558.

KPMG (2006), Annual Review. London: KPMG.

Lehman, C.R. (1990), "The importance of being earnest: gender conflicts in accounting",. Advances in Public Interest Accounting, 5, 137-157.

Lehman, C.R. (1992), “"Herstory” in accounting: The first eighty years”, Accounting, Organizations and Society, Vol. 17 No. (3-4), pp. 261-285

Lehman, C.R., and Tinker, T. (1987), "The "real" cultural significance of accounts",. Accounting Organizations and Society, Vol. 12 No. 5, pp. 513-522.

Levinson, F. and Parritt, S. (2006), "Against stereotypes: experiences of disabled psychologists". In Disability \& Psychology (eds. D. Goodley and R. Lawthorn) Basingstoke: Palgrave-Macmillan.

Lowe, D.J., Reckers, P.M.J., and Sanders, D. (2001), "The influence of gender, ethnicity and individual differences on perceptions of career progression in public accounting", International Journal of Auditing. Vol.5, No. 1, pp. 53-71.

Marin, B., Prinz, C., and Queisser, M. (Eds.) (2004), Transforming Disability Welfare Policies. Aldershot: Ashgate, and the European Centre Vienna.

Matthews, D., and Pirie, J. (2001), The auditors talk. London: Garland. 
McNicholas, P., Humphries, M. and Gallhofer, S. (2004), "Maintaining the empire: Maori women's experiences in the accounting profession", Critical Perspectives on Accounting, Vol. 15, No. 1, pp. 57-93.

Moos, R. H. (1989), "Work as human context". In M. S. Pallak and R. Perloff (Eds.), Psychology and work: productivity, change, and employment (Washington, DC, American Psychological Association).

Morrissey, C.T. (1998), "On oral history interviewing”. In R. Perks and A. Thomson (Eds.), The Oral History Reader. London: Routledge. pp 107-113.

Mowry, R.L. and Anderson, G.B. (1993), "Deaf adults tell their stories: perspectives to job advancement and on-the-job accommodations", The Volta Review, Vol. 95, No. Fall, pp. 367-377.

Oliver, M. (1990), The Politics of Disability. London: MacMillan.

Perks, R., and Thomson, A. (1998), The Oral History Reader. London: Routledge.

Pillsbury, C.M., Capozzoli, L., and Ciampa, A. (1989), A synthesis of research studies regarding the upward mobility of women in public accounting. Accounting Horizons, 3 (1), 63-70.

Prime Minister's Strategy Unit (2005), Improving the life chances of disabled people. Prime Minister's Strategy Unit. www.cabinetoffice.gov.uk/strategy/work_areas/disability.aspx.

Roulstone, A., L. Gradwell, J. Price, and L. Child. (2003), Thriving and surviving at work: Disabled peoples' employment strategies. London: Policy Press.

Shah, S. (2005), Career success of disabled high-flyers. London: Jessica Kingsley.

Shakespeare, T. (1997), Cultural Representation of Disabled People: dustbins for disavowal? In L. Barton and M. Oliver (Eds.) Disability Studies: Past Present and Future. Leeds: The Disability Press, pp. 217 - 233.

Smith, A., and Twomey, B. (2002), "Labour Market Experiences of People with Disabilities", Labour Market Trends, Vol. 8, pp. 415-427.

Smits, S.J. (2004), "Disability and Employment in the USA: the quest for best practices", Disability \& Society, Vol. 19, No. 6, pp. 647-662.

Spruill, W.G, and Wootton, W. (1995), "The Struggle of Women in Accounting: The Case of Jennie Palen, Pioneer Accountant, Historian and Poet", Critical Perspectives on Accounting, Vol. 6, No. 4, pp. 371-389.

Stevens, G.R. (2002), "Employers' perceptions and practice in the employability of disabled people: A survey of companies in Southeast UK", Disability \& Society Vol. 17, No. 7, pp. 779-96. 
Stone, D.L., and A. Colella. (1996), "A model of factors affecting the treatment of disabled individuals in organizations", Academy of Management Review, Vol. 21, No. 2, pp. 352-401.

Street, D.L., Schroeder, R.G., and Schwartz, B. (1993), "The central life interests and organizational professional commitment of men and women employed by accounting firms", Advances in Public Interest Accounting, Vol. 5, No. 2, pp. 201229.

Stuart, N., A. Watson, J. Williams, N. Meager, and D. Lain. (2002), How employers and service providers are responding to the Disability Discrimination Act 1995, Department for Work and Pensions in-house report 96. London: Department for Work and Pensions.

Thornton, P., Lunt, N. (1997), Employment Policies for Disabled People in Eighteen Countries: A Review. Social Policy Research Unit, University of York, York.

Tinker, T., and Neimark, M. (1987), The role of annual reports in gender and class contradictions at General Motors: 1917-1976. Accounting Organisations and Society, Vol. 12, No.1, pp. 71-110.

Walker, S. (1988), The Society of Accountants in Edinburgh: 1854-1914. Garland, New York.

Watson, D. and Boone, S. (1998), "The changing workforce: implications for the employment of workers who are deaf or hard of hearing", Disability Studies Quarterly, Vol. 18, No. 2, pp. 110-115.

Weber, M. (1978), Economy and Society. Berkley, CA: University of California Press.

Wilson-Kovacs, D, Ryan, M.K., Haslam, S.A., and Rabinovich, A. (2008), "Just because you can get a wheelchair in the building doesn't necessarily mean that you can still participate': barriers to the career advancement of disabled professionals", Disability \& Society, Vol. 23, No. 7, pp. 705-717

Woodhams, C. and Corby, S. (2003), "Defining Disability in Theory and Practice: A Critique of the British Disability Discrimination Act 1995", Journal of Social Policy, Vol. 32, No. 2, pp. 1-20.

Yow, V.R. (2005), Recording oral history: A guide for the humanities and social sciences. Plymouth, Devon: AltaMira Press. 
Table 1: Empirical evidence of disabled workers' experience of employment

\begin{tabular}{|c|c|c|}
\hline Authors & Participants & $\begin{array}{l}\text { Research Question and Findings } \\
\end{array}$ \\
\hline $\begin{array}{l}\text { Mowry and } \\
\text { Anderson } \\
(1993)\end{array}$ & $\begin{array}{l}\text { Interviews with } 40 \text { deaf adults in the US. } 22 \\
\text { employed, } 18 \text { unemployed. }\end{array}$ & $\begin{array}{l}\text { Perceptions of people who are deaf concerning advancement and on-the-job accommodations } \\
\text { Interviewees identified issues with barriers to advancement, supervisor insensitivity, job accommodations, } \\
\text { and communicating in the job and in groups. }\end{array}$ \\
\hline Hyde (1998) & $\begin{array}{l}\text { Questionnaire of } 60 \text { workers in sheltered } \\
\text { employment and } 32 \text { in structured } \\
\text { placements in the UK }\end{array}$ & $\begin{array}{l}\text { Experiences of disabled workers in sheltered employment or supported placements in the 1990s. } \\
\text { Disabled workers in sheltered employment suffered in (then) recent government attempts to integrate } \\
\text { disabled people into mainstream working conditions. In supported placements, disabled workers encounter } \\
\text { unequal treatment between themselves and able-bodied colleagues (e.g., low pay, inferior terms and } \\
\text { conditions). }\end{array}$ \\
\hline French (2001) & $\begin{array}{l}\text { Interviews with } 45 \text { visually impaired } \\
\text { physiotherapists in the UK }\end{array}$ & $\begin{array}{l}\text { Study of the working lives of disabled physiotherapists } \\
\text { Barriers encountered by disabled physiotherapists and strategies used to cope with their work }\end{array}$ \\
\hline Shah (2005) & $\begin{array}{l}\text { Interviews with } 31 \text { disabled professionals in } \\
\text { UK }\end{array}$ & $\begin{array}{l}\text { Experiences of disabled people in professional or leadership positions (high-flyers) } \\
\text { Detailed study of childhood experiences, education, individual personality and motivations, and career } \\
\text { choice and experiences. }\end{array}$ \\
\hline $\begin{array}{l}\text { Roulstone et al. } \\
\text { (2003) }\end{array}$ & $\begin{array}{l}\text { Interviews with } 33 \text { disabled workers in the } \\
\text { UK }\end{array}$ & $\begin{array}{l}\text { Employment strategies and sources of support used by disabled workers } \\
\text { Disabled workers used a diverse and complex strategies to survive and/or thrive in workplace. Strategies } \\
\text { were usually situation specific changing over time, with different leadership styles, corporate priorities and } \\
\text { impairment changes. } \\
\text { Workplace support (formal and informal) was central to disabled workers getting on in employment. } \\
\text { Support greatest in organisations of, and for, disabled people. }\end{array}$ \\
\hline $\begin{array}{l}\text { Levinson and } \\
\text { Parritt (2006) }\end{array}$ & $\begin{array}{l}\text { Two autobiographical accounts of working } \\
\text { as disabled psychologists in the UK }\end{array}$ & $\begin{array}{l}\text { Experiences of working in the psychology profession as a disabled person } \\
\text { Researchers document issues with work settings (the physical environment), colleagues' reactions, } \\
\text { interactions with patients and clients, how disabled psychologists function successfully, and how their } \\
\text { professional body could better support disabled psychologists. }\end{array}$ \\
\hline Foster (2007) & $\begin{array}{l}\text { Interviews with } 20 \text { disabled workers in } \\
\text { professional positions in UK public service } \\
\text { organisations }\end{array}$ & $\begin{array}{l}\text { Employee experiences of disability and negotiation of workplace adjustments } \\
\text { Negotiations on workplace adjustments were highly individualised, with bullying commonplace, and } \\
\text { outcomes depending on knowledge, attitudes and goodwill of poorly-trained line managers. }\end{array}$ \\
\hline $\begin{array}{l}\text { Wilson-Kovacs } \\
\text { et al. }(2008)\end{array}$ & $\begin{array}{l}\text { Interviews with } 14 \text { disabled workers in } \\
\text { professional or leadership positions in UK } \\
\text { public service organisations }\end{array}$ & $\begin{array}{l}\text { Barriers disabled employees face in leadership and senior positions } \\
\text { Interviews highlight lack of opportunity, lack of resources and lack of support available. Disabled leaders } \\
\text { face precarious opportunities ('glass cliff') as sole means for advancement. }\end{array}$ \\
\hline Authors (2008) & $\begin{array}{l}\text { Interviews with } 12 \text { disabled accountants in } \\
\text { the UK. }\end{array}$ & $\begin{array}{l}\text { How do institutionalized practices serve to exclude or marginalisae disabled accountants } \\
\text { Aspects of professional socialization (image, appearance, rigidity of practice, temporal commitment, impact } \\
\text { negatively of employment of disabled accountants. Professional bodies display little understanding of their } \\
\text { disabled members' needs. }\end{array}$ \\
\hline
\end{tabular}


Table 2: Description of Narrators

\begin{tabular}{|c|c|c|c|c|c|c|}
\hline Case & Pseudonym & Impairment & Employment status & $\begin{array}{c}\text { When } \\
\text { disabled? }\end{array}$ & $\begin{array}{c}\text { Qualifying } \\
\text { body }\end{array}$ & Age \\
\hline 1. & Alison & Ehlers-Danlos Syndrome $(\mathrm{H})$ & Audit senior, small regional firm & During career & $\mathrm{ACCA}$ & 29 \\
\hline 2. & Andrew & Epilepsy $(\mathrm{H})$ & Tax manager, small regional firm & $\begin{array}{l}\text { Before } \\
\text { working }\end{array}$ & ICAS & 52 \\
\hline 3. & David & Cerebral palsy $(\mathrm{V})$ & Assistant tax manager in Big 4 firm & Birth & ICAEW & 26 \\
\hline 4. & Dean & Hearing impairment $(\mathrm{H})$ & Former financial controller in commerce & During career & ICAS & 62 \\
\hline 5. & Euan & Polio (V) & Sole practitioner & $\begin{array}{l}\text { Before } \\
\text { working }\end{array}$ & ICAS & 57 \\
\hline 6. & Gwen & $\begin{array}{l}\text { Chronic depression (bipolar disorder) }(\mathrm{H}) \text {, chronic fatigue } \\
\text { syndrome }(\mathrm{V})\end{array}$ & $\begin{array}{l}\text { Unemployed, former manager in public sector } \\
\text { finance }\end{array}$ & $\begin{array}{l}\text { Before } \\
\text { working }\end{array}$ & ICAS & 40 \\
\hline 7. & James & Muscular dystrophy (V) & Former junior partner in Big 4 firm & During career & ICAEW & 63 \\
\hline 8. & Joan & Cerebral palsy (V) & Former accountant in industry & Birth & ICAS & 47 \\
\hline 9. & John & Multiple Sclerosis (V) & Former accountant in small regional firm & During career & ICAEW & 60 \\
\hline 10. & Neil & Visual impairment (V) & $\begin{array}{l}\text { Unemployed, former tax assistant in small } \\
\text { regional firm }\end{array}$ & Birth & ACCA, CTA & 39 \\
\hline 11. & Peter & Spina bifida $(\mathrm{V})$ & Financial controller in industry & Birth & ICAEW & 48 \\
\hline 12. & Stephen & Paralysis, epilepsy (as the result of stroke) (V) & Former partner in small regional firm & During career & ICAS & 55 \\
\hline
\end{tabular}

Key: $\mathrm{H}=$ hidden impairment; $\mathrm{V}=$ visible impairment. 